\title{
Saving Fred: what family practice means to medicine
}

\author{
David Loxterkamp
}

It is legend now, that Christmas Eve of 1985 . I was just a rookie on the medical staff; Fred was 73 years old and not long retired when the ambulance came to fetch him for the classic signs of a myocardial infarctionchest pressure, diaphoresis, and left arm pain. It is probably true, as he often said, that we saved Fred's life. Nursed him with oxygen, morphine, diuretics, rotating tourniquets, and an 18 gauge needle in the antecubital fossa that let a crimson stream to the basin below. Saved him without the latest fashion of baby aspirin, thrombolysis, and angioplasty. But saved him nevertheless. With science. With electrocardiograms and serum studies, pressors and antibiotics that flowed through the night while Fred and I were busy measuring each other up.

Over the next week, and with vexing succession, Fred developed cardiogenic shock, a perforating ulcer, pancreatitis, anaemia, pneumonia, and new onset diabetes. Even in the pitch of battle, I began to see how caring for Fred was a two way street. For Fred was a big man in Waldo County, even larger than his 265 pound frame. He had an extended family and wider influences and a razor sharp memory that he brandished in the art of the yarn. Our unspoken bargain was the saving of his life for my reputation.

This local potentate confounded convention. Instead of spending his allotted healthcare dollar in the last year of life, Fred spread it out like a hand of cards over a decade and a half. For "fluid," for "breathing," for weakness, he would draw a few days here, spend a couple more there, and so tally another 250 hospital days over 39 separate admissions.

With each new admission, the diagnosis became less obvious and important. His shortness of breath never squared with the changes seen on his chest radiograph, but we treated him anyway as if he had worsening emphysema, fluid on his lungs, and a hidden pneumonia. It is probably true, as was rumoured by the family, that a spat with the Mrs sent him in more often than not. And that a better judge of his prognosis was the washcloth he draped over the broad dome of his brow-smooth as in "sailing," bunched as in "nerves," or lost as in "all hope."

I cannot tell you how many times I put a stethoscope to his barrel chest, wrapped his swollen legs, threaded a Foley catheter, trimmed his nails, drew blood with a butterfly through the back of his leathery hands. How often I heard, in the process, stories of the chicken business, hauling ice, or commanding the local constabulary. How many home visits my partners and I made, or the visiting nurses whom Alice would unceremoniously dismiss because of the lines they crossed in the shifting threshold between dependence and betrayal.

There comes a time when the tools of a trade acquiesce to an opportune moment, to the intangible gift of friendship, when a man and his warmth, the hatch of a grin and the way he calls you "Doc" rises above the business that brought you. And you come to realise-to paraphrase St Alban of Milan-that the doctor who cares for the sick does not bestow a service but pays a debt. Herein lies the redemptive side of medicine, when doctors discover the value of a life they save, knowing that it in some way it is their own.

\section{Photography, mirror of general practice}

Family doctors operate in a world apart from the academic centres where they trained. We speak a similar tongue of signs and symptoms; we borrow from the same battery of tests. But the rationale, our raison d'etre, rises up from below and surrounds us. As the result of countless trivial encounters, we come to see the world through a different lens. Janet Malcolm's book, Diana and Nikon, makes the point vividly by way of metaphor. ${ }^{1}$ In a marvellous collection of essays written largely for The New Yorker, she stalks the "the true business of photography."

Malcolm contends that photography crossed a watershed when it began to study the snapshot. The moment was 1959; the occasion was the publication of The Americans by a Swiss born Jewish immigrant, Robert Frank. Frank had traversed the dusty, deserted byways of the United States to bring us shocking images of motorcycle gangs, Fourth of July celebrations, urinals, automobile accidents, billboards. His subjects were scruffy and crass. His prints lacked the pictorial values of his predecessors-composition, design, tonal balance, print quality. As Malcolm says, he produced photographs that looked "as if a kid had taken them while eating a Popsicle."1 But, like no one before him, Frank understood the camera's unique ability to show us the world in its worst possible light. He transported us to unpleasant places where few dared to tread, and he developed a nasty preference for those aspects of our human nature that we most disdained. But misanthropy is inherent to the camera,

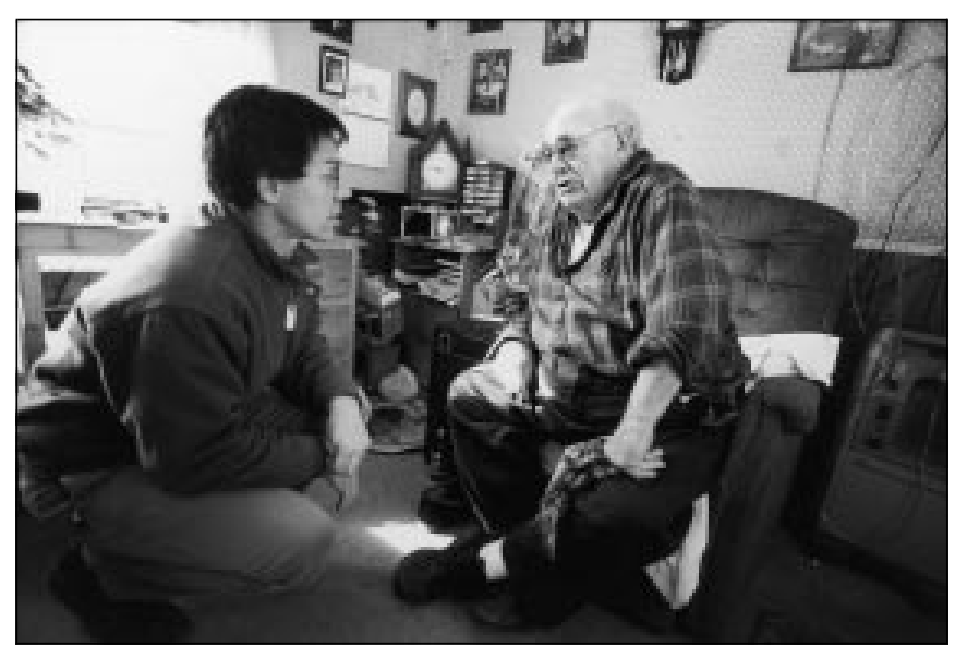

Family doctors see the world through a different lens. One of a series of photographs from LIFE Magazine, June 1998. The photographer is Lynn Johnson; the doctor is David Loxterkamp; the patient is not Fred but a contemporary and friend of his, Phil Spaulding 
not the photographer. John Kouwenhoven explains: "Our eyes are looking for what we want to know; the camera can be aimed in the direction whence we think that information may come. But left to itself it cannot ... help showing us what we have no interest in seeing." 1

Among Frank's many followers, Garry Winogrand made pictures "so raw and uncontrived that the unforewarned could take them for snapshots." $\mathrm{He}$ mocked the very notion of professionalism - the sharp distinction between a professional who can control and predict his results and the amateur who stumbles into a good picture by accident. It was Winogrand who coined the oft repeated line, "I photograph to find out what something will look like photographed."

Chauncy Hare's Interior America captured Americans in their living rooms and kitchens surrounded by Middle American decor and the latest appliances. Because his vision was that of an insider's-knowing and intimate, loving and hating - the pictures strike home. He showed us consumers with bad taste, disgusting habits, and low values who are indisputably like us. "What we don't want to know, and what our Kodacolor snapshots keep telling us," concludes Malcolm, "is that we are all the same. The electric cord binds us all together; at our most individual we appear as but slightly different brands of [the same] consumer."

The modus operandi of Frank, Winogrand, and Hare is our own: untidy methods, surly subjects, chance encounters, therapeutic probes, anecdotal observations, faith in the decisive moment. This is the bread and butter of general practice. What we contribute to the greater glory of medicine is not (only) the innovation of tools and their efficiency. Leave that to the time manager, the technician, or the computer. We strive to perfect the doctor, his or her insights and the depth of feeling. We are concerned with the quality of the doctor's relationships and the mirror they provide.

\section{Management, monoliths, and methods}

I burden my less experienced colleagues with one line of advice: Forget diagnosis and treatment. They will be decided, but general practice is all about management. It is about helping ill people edge past their fears and doubts and deeper wounds; it is about managing the incalculable through the unforeseen.

Don't misunderstand. I am grateful for the tools that have been given to me-clinical knowledge, discipline, and agents that often work, just as the instructions say. But I recognise, too, that the academic medical centre is a monolith to truth, a constructed knowledge, a simultaneously revealing and obscuring wisdom heavily influenced by undeclared forces and potent biases-the bias for good and measurable outcomes, the pressure to publish, a dependency on the pharmaceutical industry's largess. Even in general practice there is no certainty that the "true business" of our profession will ever yield to narrative reports and personal essays, videotaped encounters and apprenticed observations, Balint groups and collegial support.

For those of us who are devoted to general practice, our true business is serving the sick as a moral respon- sibility. That is all. Our achievement is more like a snapshot-not often clear or beautiful or well composed, but revealing in the virtues we strive for, the relationships we form, and all the chaotic elements that clutter the clinical frame (including the fleeting shadow of the doctor). We are compensated for a lack of technical expertise by the variety of methods at our disposal-the test of time, the use of our senses, the auger of compassion propelling us into the good work and real lives of our patients.

Forgive me for my wariness of words and theories that explain the healer's art. They seem too tidy, conclusive, and at odds with the evidence. Even my own words warrant your suspicion, considering their source and my need for consolation. How can you record what layers out over the years, emerges like night vision, speaks to us in silence and through the suffering and joys of our patients as they give birth and live and slowly die? Thomas Merton, in his introduction to a book of sayings by the Desert Fathers, foretold the modern dilemma: "What good will it do us to know merely that such things were said? The important thing is that they were lived. That they flow from an experience of the deeper levels of life."2

\section{Honouring Fred}

Nearly 300 townspeople packed into the First Baptist Church on a spare and sparkling January day. Folding chairs were snapped open along the aisles and in the choir loft, filling every available surface in order to accommodate the throng who had come to honour Fred. How many of them did I know through this one man? How much more of Fred did I know because of them?

Enter the doctor, late (as usual) in the arc of an active life. Where is the strapping football player who starred for Crosby High, the farmer and facile teamster, the hauler of leviathan ice blocks whose shards delighted the neighbourhood kids, the Waldo County sheriff, Belfast chief of police, church trustee and deacon of the First Baptist Church? He was a family man, protector of children's fears and moulder of their fibre, progenitor of five children, 22 grandchildren, 45 great grandchildren, and two great great grandchildren, all here today. After the elegies and hymns and poems, the retired minister rose to speak on tottering legs but with a voice like a vice. Even to the good reverend, Fred had been a father, having personally introduced him to most of his flock along back roads and logging trails whose locations and navigation is now lost to the ages. But the legacy is not.

Let the intensivists and researchers make their progress. It increases us all. But for the family practitioner, it is the years scuffed softly underfoot-the odd moments of noting and welcoming what ripples from a single, momentary act like saving Fred-that remains our saving grace.

1 Malcolm J. Diana and Nikon: essays on photography. New York: Aperture, 1997.

2 Merton T. The wisdom of the desert. New York: New Directions, 1960. 